\title{
Initiation of Snowball Earth with volcanic sulfur aerosol emissions
}

\section{Citation}

Macdonald, F. A., and R. Wordsworth. 2017. "Initiation of Snowball Earth with Volcanic Sulfur Aerosol Emissions." Geophysical Research Letters. doi:10.1002/2016gl072335.

\section{Published Version}

10.1002/2016GL072335

\section{Permanent link}

http://nrs.harvard.edu/urn-3:HUL.InstRepos:34858094

\section{Terms of Use}

This article was downloaded from Harvard University's DASH repository, and is made available under the terms and conditions applicable to Other Posted Material, as set forth at http:// nrs.harvard.edu/urn-3:HUL.InstRepos:dash.current.terms-of-use\#LAA

\section{Share Your Story}

The Harvard community has made this article openly available.

Please share how this access benefits you. Submit a story.

Accessibility 


\section{Geophysical Research Letters}

\section{RESEARCH LETTER}

10.1002/2016GL072335

Key Points:

- The Franklin large igneous province was coincident with onset of the Sturtian Snowball Earth glaciation

- Multiyear to decadal fissure eruptions can inject enough sulfur aerosols to the stratosphere to initiate Snowball Earth

- Cold background climate states are sensitive to ice-albedo catastrophe because tropopause height is a function of surface temperature

Supporting Information:

- Supporting Information S1

Correspondence to:

F. A. Macdonald,

fmacdon@eps.harvard.edu

\section{Citation:}

Macdonald, F. A., and R. Wordsworth (2017), Initiation of Snowball Earth with volcanic sulfur aerosol emissions, Geophys. Res. Lett., 44, 1938-1946, doi:10.1002/2016GL072335.

Received 12 DEC 2016 Accepted 7 FEB 2017

Accepted article online 8 FEB 2017

Published online 22 FEB 2017

(c)2017. American Geophysical Union. All Rights Reserved.

\section{Initiation of Snowball Earth with volcanic sulfur aerosol emissions}

\author{
F. A. Macdonald ${ }^{\mathbf{1}}$ iD and R. Wordsworth ${ }^{1,2}$ iD \\ ${ }^{1}$ Department of Earth and Planetary Sciences, Harvard University, Cambridge, Massachusetts, USA, ${ }^{2}$ School of Engineering \\ and Applied Sciences, Harvard University, Cambridge, Massachusetts, USA
}

Abstract We propose that the first Neoproterozoic Snowball Earth event, the Sturtian glaciation, was initiated by the injection of sulfate aerosols into the stratosphere. Geochronological data indicate that the Natkusiak magmatic assemblage of the Franklin large igneous province coincided with onset of the Sturtian glaciation. The Natkusiak was emplaced into an evaporite basin and entrained significant quantities of sulfur, which would have led to extensive $\mathrm{SO}_{2}$ and $\mathrm{H}_{2} \mathrm{~S}$ outgassing in hot convective plumes. The largest of these plumes could have penetrated the tropopause, leading to stratospheric sulfate aerosol formation and an albedo increase sufficient to force a Snowball. Radiative forcing was maximized by the equatorial location of the Franklin and the cool Neoproterozoic background climate, which would have lowered the tropopause height, increasing the rate of stratospheric aerosol injection. Our results have implications for understanding Phanerozoic mass extinction events, exoplanet habitability, and aerosol perturbations to the present-day climate.

\section{Introduction}

The Neoproterozoic Era witnessed two Snowball Earth glaciations, the $~ 717-660$ Ma Sturtian glaciation and the $\sim 645-635 \mathrm{Ma}$ Marinoan glaciation [Rooney et al., 2015]. These glaciations are the largest episodes of climate change in the geological record [Hoffman and Schrag, 2002], yet we do not understand how they were initiated. Of particular importance is the transition into the first Neoproterozoic Snowball event, the Sturtian glaciation (Figure 1), which was preceded by over one billion years of apparently clement conditions.

Previously, it has been proposed that the Neoproterozoic climate was cool as a result of the predominance of equatorial continents with newly rifted margins and increased planetary weatherability [Cox et al., 2016; Godderis et al., 2003; Macdonald et al., 2010; Rooney et al., 2014; Schrag et al., 2002]. The rifting of the supercontinent Rodinia occurred near the equator from 850 to $650 \mathrm{Ma}$ [Li et al., 2013] and was accompanied by the emplacement of multiple large igneous provinces (LIPs), including the Franklin LIP (Figure 1a). These newly rifted margins and the emplacement of rift-related LIPS at low latitude would have increased global weatherability [Godderis et al., 2003; Macdonald et al., 2010; Rooney et al., 2014] and phosphorous input to the oceans, which would have led to more organic carbon productivity and burial in tropical deltas [Cox et al., 2016]. A low-latitude paleogeography may have also limited the "land area feedback" in which silicate weathering rates decline with the growth of ice sheets on high-latitude continents [Schrag et al., 2002]. Hence, Neoproterozoic paleogeography may have been more sensitive to ice-albedo runaway. Alternatively, it has been proposed that long-term Neoproterozoic cooling was due to decreased volcanic outgassing [McKenzie et al., 2016]. Whether it was a change in geological sources or sinks of $\mathrm{CO}_{2}$, or a change in the sensitivity of the silicate weathering feedback (in the sense of Maher and Chamberlain [2014]), the fact that there were two Neoproterozoic Snowball Earth events in rapid succession suggests that background conditions played an important role.

From this cool background climate state, various proximal triggers for the Snowball transition have also been proposed to overcome the silicate weathering feedback, including short-term perturbations to the greenhouse gas inventory [Schrag et al., 2002; Tziperman et al., 2011] and/or the planetary albedo [Bendtsen and Bjerrum, 2002; Feulner et al., 2015; Stern et al., 2008]. Previous explanations invoking a short-term drawdown of $\mathrm{CO}_{2}$ or methane were motivated by an apparent correlation between perturbations to the carbon cycle and the onset of glaciation [Schrag et al., 2002; Tziperman et al., 2011]. However, recent geochronology has demonstrated that the pre-Sturtian Islay carbon isotope excursion occurred more than 10 Myr before the initiation of the Sturtian by 716.5 \pm 0.2 Ma [Macdonald et al., 2010; Rooney et al., 2014; Strauss et al., 2014], ruling out a direct link. Albedo changes due to the emergence of eukaryotic algae [Feulner et al., 2015] rely on the coincidence of a putative evolutionary milestone for which there is no evidence. Finally, others 


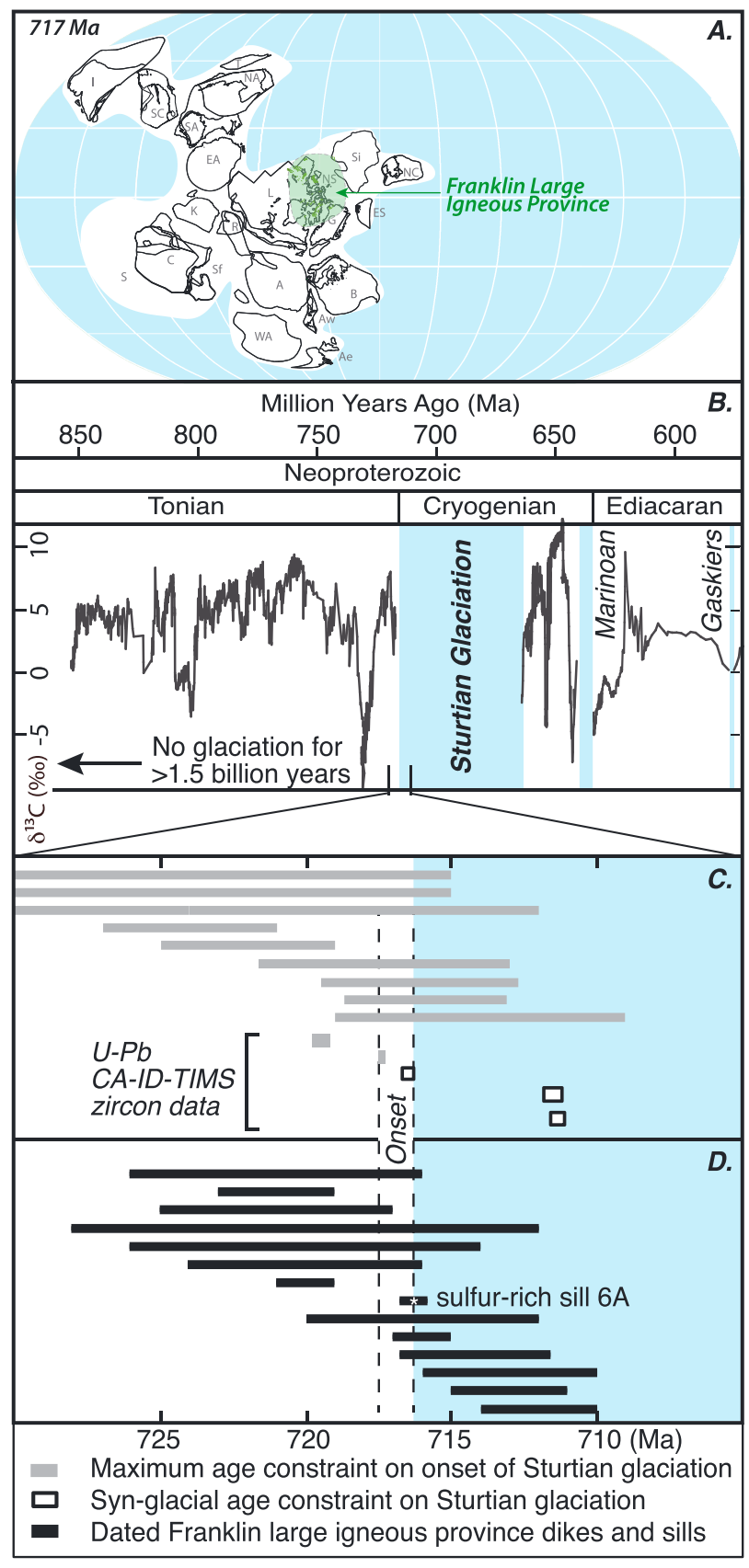

Figure 1. Paleogeographic and geochronological constraints on the onset of the Sturtian glaciation and the Franklin Large Igneous Province. (a) Neoproterozoic paleogeography modified from Li et al. [2013] and Zhang et al. [2013]). I = India; SA = southern Australia; NA = northern Australia; T = Tarim; $\mathrm{SC}=$ South China; $\mathrm{M}=$ Mongolia; $\mathrm{EA}=$ East Antarctica; $\mathrm{Si}=$ Siberia; $\mathrm{NC}=$ North China; L = Laurentia; NS = North Slope; ES = East Svalbard; G = Greenland; $\mathrm{B}=$ Baltica; $\mathrm{A}=$ Amazonia; $\mathrm{WA}=$ West Africa; $\mathrm{Aw}=$ western Avalonia; $\mathrm{Ae}=$ eastern Avalonia; $\mathrm{Sf}=$ So Francisco; $\mathrm{C}=$ Congo; $\mathrm{K}=$ Kalahari; $\mathrm{R}=$ Rio Plata. (b) Neoproterozoic timeline with carbon isotope chemostratigraphy, modified from Cox et al. [2016]. (c) Geochronological constraints on the onset of the Sturtian glaciation. (d) Geochronological constraints on the Franklin large igneous province. Geochronological data and sources are in Table S1 in the supporting information. Note that the Franklin large igneous province erupted at the equator, and the most precise date of sulfur-rich sills correlate with onset of the Sturtian glaciation, but the carbon isotope excursions do not. have invoked albedo forcing by meteorite impacts or explosive felsic volcanism [Bendtsen and Bjerrum, 2002; Stern et al., 2008]. However, there is no evidence for a major meteorite impact at the time of the Sturtian onset, and albedo perturbations on the timescale of less than a year are unlikely to drive runaway glaciation. Here we propose an alternative scenario, in which multiyear to decadal emissions of sulfur from the Franklin LIP were the proximal trigger that caused the Sturtian Snowball transition.

\section{Synchronicity of the Sturtian Snowball Glaciation With Eruption of the Franklin LIP}

While the Islay carbon isotope excursion is not synchronous with the Sturtian Snowball glaciation (Figure 1b), the emplacement of the largest Neoproterozoic LIP is. The most precise date on the initiation of the Sturtian glaciation comes from Yukon, Canada, where onset is bracketed between $\mathrm{U} / \mathrm{Pb}$ zircon dates of $717.4 \pm 0.1$ and $716.5 \pm 0.2 \mathrm{Ma}$ [Macdonald et al., 2010] (Figure 1c). These dates are indistinguishable from the most precise date on the Franklin LIP of $716.3 \pm 0.5 \mathrm{Ma}$ [Macdonald et al., 2010] (Figure 1d). Volcanic rocks associated with the Franklin LIP cover an area of $>3 \mathrm{Mkm}^{2}$ over northern Laurentia and southern Siberia [Ernst et al., 2016] (Figure 1a), which was at equatorial latitudes during its formation [Denyszyn et al., 2009b; Macdonald et al., 2010]. On Victoria Island of the Canadian Arctic, the Franklin LIP is represented by the Natkusiak magmatic assemblage, which consists of basalt and gabbroic dikes and sills that intruded carbonate, organic-rich shale, and sulfur evaporite of the Shaler Supergroup [Dostal et al., 1986]. The amount 
of metamorphic $\mathrm{CO}_{2}$ released from the emplacement of gabbroic sills of the Natkusiak assemblage was small relative to background levels and likely did not have a significant climate effect [Nabelek et al., 2014]. However, due to melting and assimilation of sulfur from the evaporites, many of the sills and dikes have extremely high sulfur concentrations, ranging from 100 to 100,000 ppm [Bedard et al., 2016], and sulfur isotope compositions indicative of contamination from entrained sedimentary rocks (see Figure S2 in the supporting information). Finally, these sulfur-rich sills are the same sills that have been dated at $716.3 \pm 0.5 \mathrm{Ma}$, which is synchronous within error with the Sturtian glaciation onset [Macdonald et al., 2010] (Figure 1c). Inspired by these observations, we propose that the emplacement of the Franklin LIP near the equator into a sulfur-rich basin and subsequent sulfur emission to the atmosphere was the critical event that initiated the Sturtian Snowball Earth.

\section{Volcanic Plume, Aerosol, and Climate Modeling}

During a volcanic eruption, sulfur is outgassed as a combination of $\mathrm{SO}_{2}$ and $\mathrm{H}_{2} \mathrm{~S}$ [Textor et al., 2003]. Once in the atmosphere, these gases react with $\mathrm{O}_{2}, \mathrm{H}_{2} \mathrm{O}$, and $\mathrm{OH}$ to form $\mathrm{H}_{2} \mathrm{SO}_{4}$, which condenses with $\mathrm{H}_{2} \mathrm{O}$ onto condensation nuclei to form radiatively active sulfate aerosols [Turco et al., 1979a]. Weak volcanic plumes inject sulfur into the troposphere, where sulfate aerosols are consumed in days to weeks and have little long-term radiative effect [Chin et al., 1996]. Conversely, strong plumes penetrate the tropopause and reach the stratosphere, where $\mathrm{H}_{2} \mathrm{SO}_{4}$ aerosols can have lifetimes of a year or more [McCormick et al., 1995].

Unlike explosive volcanic eruptions such as the 1991 Pinatubo event, the eruptions associated with the Franklin LIP were basaltic in nature, leading to large fire fountains that would have driven hot convective plumes into the atmosphere [Stothers et al., 1986]. This has two major consequences. First, the probability of a hot volcanic plume penetrating the tropopause is determined by the degree of thermal energy at the plume base, which can be very high given that basaltic magmas typically have temperatures of $1000 \mathrm{~K}$ or more. Second, and most critically, basaltic eruption sequences during LIP formation can occur over very long time periods (years to decades), potentially causing a much longer-term climate impact [Self et al., 2014].

To evaluate our hypothesis that the Sturtian glaciation was initiated by the creation of sulfate aerosols from equatorial basaltic volcanism, we modeled the height to which hot, buoyant sulfur-bearing plumes from fire fountains could reach in the atmosphere, the chemical and microphysical evolution of sulfur in the atmosphere, and the radiative effects of sulfate aerosols once they formed. To simulate the volcanic plumes, we used a one-dimensional steady state model incorporating turbulent entrainment. This relatively simple approach is justified based on extensive previous comparisons with observations and laboratory experiments (see discussion in the supporting information). Our sulfur aerosol microphysics model is sectional (82 bins total) and incorporates particle growth, coagulation, sedimentation, and mixing. Sulfate aerosol radiative forcing was calculated using Mie theory and a one-dimensional radiative-convective correlated- $k$ model [Wordsworth et al., 2010; Wordsworth et al., 2013]. We also used this model to provide atmospheric temperature-pressure profiles as input to the volcanic plume model. A complete description of our modeling approach is given in the supporting information.

\section{Results}

First, we investigated the dependence of the maximum thermal volcanic plume height on the strength of an individual Franklin LIP eruption and on the background climate. Our modeling indicates that plume height is a strong function of volume eruption rate, with eruption rates of $10^{4}-10^{5} \mathrm{~m}^{3} / \mathrm{s}$ leading to plume heights greater than the present-day tropical tropopause $(\sim 12 \mathrm{~km})$ under Neoproterozoic atmospheric conditions (Figure 2). We estimate these rates to be representative of the peak values produced during eruptions associated with the Franklin LIP (see supporting information). Furthermore, our climate modeling shows that tropopause height is a strong function of surface temperature (Figure 2a). This is because a warmer surface injects more water vapor into the atmosphere, reducing the lapse rate. Hence, very warm climates can "shield" the Earth from stratospheric aerosol injection by even the largest volcanic plumes [see also Glaze et al., 2017]. Conversely, a cool background climate in the Neoproterozoic would have made it a particularly dangerous time for a sequence of large basaltic eruptions to occur. 

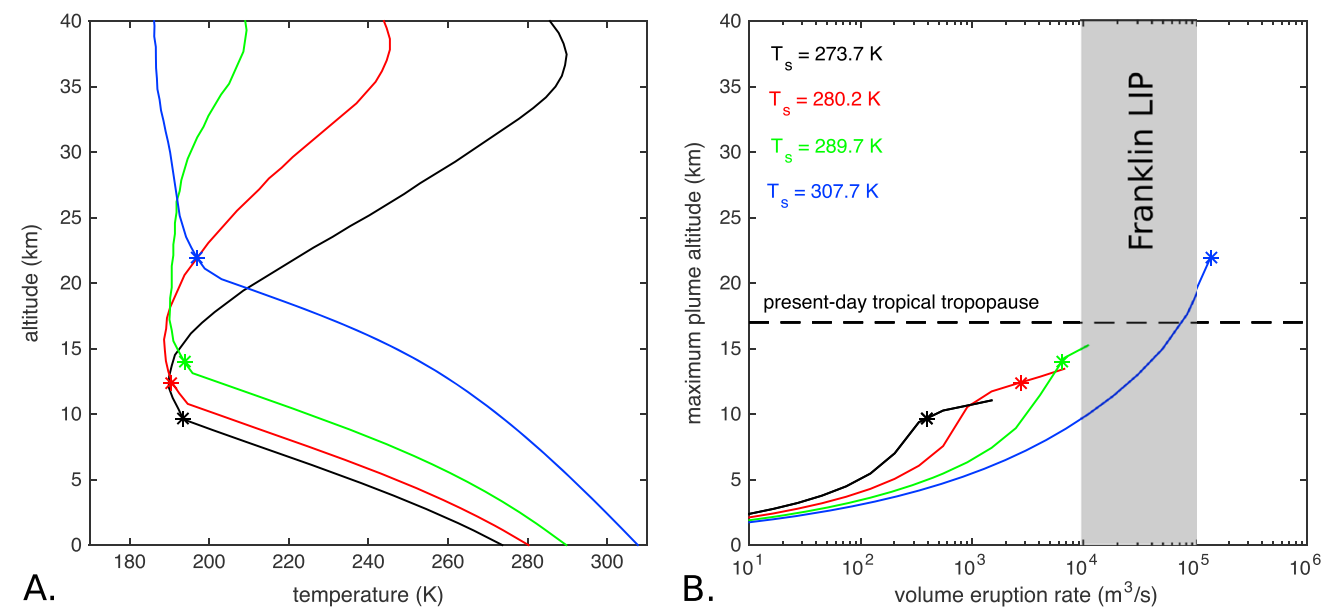

Figure 2. (a) Equilibrium atmospheric temperature profiles produced from the radiative-convective climate model for varying $\mathrm{CO}_{2}$ concentrations under Neoproterozoic conditions. The black, red, green, and blue lines correspond to simulations where the background $\mathrm{CO}_{2}$ levels were 30,300,3000, and 30,000 ppm, respectively. (b) Maximum Franklin LIP plume height as a function of volume eruption rate. In both panels, asterisks indicate tropopause height, defined as where the lapse rate first drops below $2 \mathrm{~K} / \mathrm{km}$. The grey box brackets the maximum plausible volume eruption rate during formation of the Franklin LIP (see the supporting information).

Our microphysical model converts $\mathrm{SO}_{2}$ and $\mathrm{H}_{2} \mathrm{~S}$ gas to $\mathrm{H}_{2} \mathrm{SO}_{4}$ aerosols on a time scale of $30-40$ days. Once formed, the aerosols remain in the stratosphere for 1-2 years, with the aerosol loading peaking in the first 3-6 months, in agreement with observations of the 1991 Pinatubo eruption (see the supporting information). We find that the radiative forcing caused by episodic injections of $\mathrm{SO}_{2}$ into the equatorial stratosphere increases with the quantity of $\mathrm{SO}_{2}$ injected (Figure 3a), but the increase is sublinear due to particle coagulation, which increases mean particle size and sedimentation rate for large eruptions [Pinto et al., 1989]. For a single eruption, mean global forcing in the following year increases from $-2.7 \mathrm{~W} / \mathrm{m}^{2}$ given $20 \mathrm{Mt} \mathrm{SO} \mathrm{S}_{2}$ injection (cf. Pinatubo [McCormick et al., 1995]) to $-12 \mathrm{~W} / \mathrm{m}^{2}$ for $500 \mathrm{Mt} \mathrm{SO}_{2}$ (sensitivity to parameters described in the supporting information). Estimating the rate at which sulfur was released from the Franklin LIP on a decadal time scale is challenging, but $500 \mathrm{Mt} / \mathrm{yr}$ is similar to estimates of $\mathrm{SO}_{2}$ release rate from more recent LIPs [Self et al., 2014]. For comparison, the radiative forcing due to $\mathrm{CO}_{2}$ doubling on the present-day Earth is around $3.7 \mathrm{~W} / \mathrm{m}^{2}$ [Myhre et al., 1998].

The eruption sequence of fissure eruptions associated with a LIP is poorly constrained. The best historical ana$\log$ is the 1783-1784 Laki fissure eruption in Iceland, which emitted $\sim 122 \mathrm{Mt} \mathrm{SO}{ }_{2}$ over 8 months with $\sim 10$ pulses that produced eruptive columns extending 9-13 km [Thordarson and Self, 2003]. However, many larger flow fields have been identified in the geological record, which require longer total durations [Self et al., 2014]. If these eruptions had higher magma output rates than Laki, different types of lava would have been produced. For example, using peak output rates from Hawaii and Laki, Thordarson and Self [1998] estimated that the $1300 \mathrm{~km}^{3}$ Roza flow field of the Columbia River Basalt Group formed in 10-20 years. Larger flows, such as those associated with the Deccan and Siberian Traps, may have lasted an order of magnitude longer [Self et al., 2014] and had multiple eruptive centers. Nonetheless, because a robust eruption time series for a multiyear fissure eruption does not exist, particularly for the sulfur release from an fissure eruption through a sulfur-rich basin, we model the radiative effect of pulsed yearly equatorial volcanic eruptions under Neoproterozoic conditions assuming 20,100, and $500 \mathrm{Mt}$ of $\mathrm{SO}_{2}$ injection to the stratosphere (Figure 3a). This covers the range of $\mathrm{SO}_{2}$ emissions from the historical Pinatubo and Laki eruptions over longer time periods and also explores the larger $\mathrm{SO}_{2}$ concentrations estimated for the Franklin LIP.

The ability of volcanic aerosols to force a Snowball transition depends on both the starting climate state and on the rate at which the upper layers of the tropical ocean can cool. Based on radiative-convective modeling, we estimate that $\mathrm{a}-10 \mathrm{~W} / \mathrm{m}^{2}$ global mean aerosol radiative forcing would be sufficient to cause runaway glaciation for $\mathrm{CO}_{2}$ levels of $3000 \mathrm{ppm}$ (Figure $3 \mathrm{~b}$ ). These $\mathrm{CO}_{2}$ levels yield approximately present-day global mean temperatures in our model given the fainter Neoproterozoic Sun. For lower background $\mathrm{CO}_{2}$ levels, as might 
A.
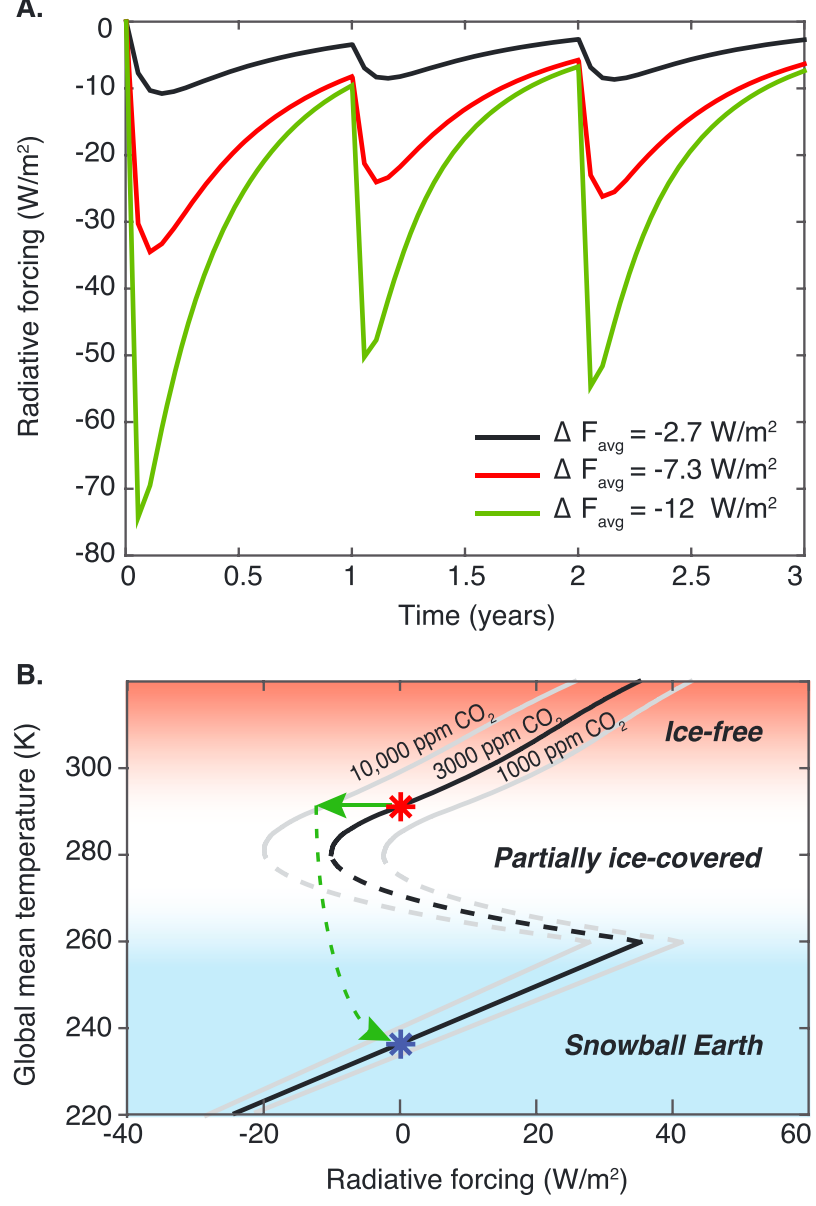

Figure 3. The effect of volcanic sulfate aerosol emission on global climate. (a) Equatorial radiative forcing due to yearly equatorial volcanic eruptions under Neoproterozoic conditions. The black, red, and green lines show simulations assuming 20,100, and $500 \mathrm{Mt}$ of $\mathrm{SO}_{2}$ injection to the stratosphere. Annual global mean forcings are also displayed. (b) Bifurcation diagram of global mean temperature versus radiative forcing defined as the difference between outgoing longwave radiation and absorbed solar radiation. The dashed lines are unstable states. Starting from a mean surface temperature close to present day (red star), a negative radiative forcing of $<-10 \mathrm{~W} / \mathrm{m}^{2}$ is sufficient to push the Neoproterozoic Earth (green line) into a Snowball state (blue star). Starting from a colder initial state, the required radiative forcing is lower. be expected in a cool background climate, a Snowball transition could have been caused by a correspondingly lower radiative forcing. A simple calculation assuming an ocean mixing layer depth of $50 \mathrm{~m}$ yields a time scale of order 3 years to drive equatorial sea surface temperatures to the freezing point of water and commence a Snowball transition (see the supporting information). Hence, a sequence of large, sulfur-rich eruptions of the type shown in Figure 3a may have been sufficient to drive a runaway icealbedo event.

Estimates of the Snowball cooling time scale from present-day conditions using general circulation models coupled to a dynamic ocean yield longer time scales (decades to several hundred years, depending on the initial climate state), due to the enhanced vertical ocean mixing driven by surface cooling in those models [Voigt et al., 2011]. Many aspects of mixing in the present-day ocean remain poorly captured by numerical models [Wunsch and Ferrari, 2004], so the extrapolation to the Snowball regime is challenging. Nonetheless, if these estimates are robust, they suggest that the climate state before the Franklin LIP erupted would have needed to be colder than that of present-day Earth to allow sulfate aerosol forcing to drive a transition. They also suggest that another reason the $14.98 \mathrm{Ma}$ Roza flow failed to initiate a Snowball was because it erupted during the Miocene climatic optimum, when higher temperatures would have required a significantly longer time scale to freeze the surface ocean.

\section{Discussion}

If the Franklin LIP caused a Snowball Earth, then why are other LIPs not also associated with Snowball Earth events? The Siberian Traps, which erupted around $250 \mathrm{Ma}$ at the end of the Permian, are similar in size to the Franklin LIP, but instead of cooling, they appear to be associated with warming and extinction [Ganino and Arndt, 2009]. Another LIP, the Central Atlantic Magmatic Province (CAMP), may have caused temporary cooling followed by warming [Schoene et al., 2010]. The different outcomes are likely related to several factors: the background climate conditions, changes in background planetary albedo with different paleogeography, the latitude of the eruptions, the composition of the country rock that the LIPs were emplaced into (a sulfate-rich basin, coal deposits, and an ancient mountain belt for the Franklin, Siberian Traps, and CAMP, respectively), and timing of $\mathrm{SO}_{2}$ injection relative to the cumulative release of gases such as $\mathrm{CO}_{2}$. Although Neoproterozoic paleogeography likely favored a cool climate [Li et al., 2013; Marshall et al., 1988], the Siberian Traps and CAMP erupted during the ice-free Late Permian and Late Triassic, respectively, when warm conditions 
extended to Earth's polar regions [Taylor et al., 1992]. Consequently, there would have been a higher tropopause that would have prevented stratospheric aerosol injection by all but the most powerful volcanic eruptions (Figure 2). Moreover, the Siberian Traps erupted at high latitude, whereas the CAMP and Franklin LIP erupted at equatorial latitudes [Denyszyn et al., 2009b]. Consequently, albedo changes associated with the Siberian Traps would have primarily affected mid-to-high latitudes in one hemisphere, whereas the CAMP and Franklin LIP would have maximized albedo at low latitude, where solar forcing is highest. Because aerosol radiative forcing is most negative when surface albedo is low, and a high-latitude eruption in a cold climate occurs over snow or sea ice, an equatorial eruption is far more effective at forcing a Snowball transition than a high latitude one (see the supporting information). Deeper in Earth's past, in the Archean and Proterozoic, a warmer climate caused by elevated levels of $\mathrm{CO}_{2}$ or other greenhouse gases [e.g., Feulner, 2012; Wordsworth and Pierrehumbert, 2013b] may have elevated the tropopause sufficiently to shield the Earth continuously from significant stratospheric sulfate aerosol injection.

The geological record preserves evidence for two Cryogenian glaciations, the Sturtian and the Marinoan. Although there is not evidence for a LIP during the onset of the Marinoan glaciation, this may be a matter of preservation. The low-latitude rifting of Rodinia continued throughout the Neoproterozoic, and it is likely that this was associated with additional LIPs. Geochronological constraints suggest that the Sturtian glaciation lasted $\sim 58 \mathrm{Myr}$ and that the nonglacial interlude before the Marinoan started was short, between 8.6 and 19.4 Myr [Rooney et al., 2014]. If planetary weatherability remained high during the Cryogenian due to continued low-latitude paleogeography and recently emplaced continental flood basalt provinces [Cox et al., 2016], transport-limited weathering in the aftermath of the Sturtian glaciation may have returned the Earth on a $10 \mathrm{Myr}$ time scale to a climate state sensitive to further short-term perturbations in the planetary albedo [Mills et al., 2011]. After the Marinoan glaciation, the removal of a basaltic carapace and drift of continents to higher latitudes [ $L i$ et al., 2013] likely reduced global weatherability and climate sensitivity.

\section{Conclusion}

Based on a combination of geological evidence and atmospheric modeling, we have proposed that the proximal trigger for the Sturtian Snowball Earth was a sudden increase in planetary albedo caused by the emission of sulfate aerosols from basaltic volcanism. Further tests of our hypothesis will be possible via tighter constraints on the geochronology of the Sturtian glaciation and the Franklin LIP, and better estimates of sulfur release with melt inclusion studies along with three-dimensional coupled ocean-atmosphere modeling of the climate effect of stratospheric aerosol emissions. Mercury anomalies have been observed in sedimentary records that span the Permian-Triassic and Triassic-Jurassic boundaries and have been attributed to the Siberian Traps and CAMP, respectively [Thibodeau and Bergquist, 2017, and references therein]. Our model predicts that similar mercury signals will be present in sedimentary successions deposited during onset of the Sturtian glaciation.

Our proposed scenario for initiation of the Sturtian has several important implications beyond the Neoproterozoic. In the Phanerozoic, the correlation of LIPs and meteorite impacts with both glaciations and mass extinction events has long suggested a causal link. However, our results imply that the timing and location of major volcanic and impact events may matter as much as, or more than, their overall magnitude. For exoplanets, our results indicate that volcanically active planets may be much more vulnerable to Snowball transitions than traditional habitable zone ideas based on the carbonate-silicate cycle [Kasting et al., 1993] would suggest. Finally, if the largest known glaciation event in Earth's history was indeed triggered by stratospheric sulfate aerosols, this should give some caution to similar geo-engineering strategies proposed recently to decrease or eliminate anthropogenic climate change [Rasch et al., 2008].

Acknowledgments

The supporting information describes the materials and methods used, and model validation and sensitivity tests; includes four tables and 10 figures, and cites the additional references.

\section{References}

Anderson, G. P., S. Clough, F. Kneizys, J. Chetwynd, and E. P. Shettle (1986), AFGL atmospheric constituent profiles (0.120 km), Rep., DTIC Document.

Baldwin, G. J., E. C. Turner, and B. S. Kamber (2016), Tectonic controls on distribution and stratigraphy of the Cryogenian Rapitan iron formation, northwestern Canada, Precambrian Res., 278, 303-322.

Barkstrom, B. R. (1984), The Earth Radiation Budget Experiment (ERBE), Bull. Am. Meteorol. Soc., 65(11), 1170-1185.

Bedard, J. H., et al. (2012), Falut-mediated melt ascent in a Neoproterozoic continental flood basalt province, the Franklin sills, Victoria Island, Canada, Geol. Soc. Am. Bull., 124(5/6), 723-736. 
Bedard, J. H., et al. (2016), Geochemical database of Franklin sills, Natkusiak Basalts and Shaler Supergroup rocks, Victoria Island, Northwest Territories, and correlatives from Nunavut and the mainland, Geol. Surv. Canada Open File, 8009, 1.

Bendtsen, J., and C. J. Bjerrum (2002), Vulnerability of climate of Earth to sudden changes in insolation, Geophys. Res. Lett., 29(15), 1706, doi:10.1029/2002GL014829.

Black, B. A., L. T. Elkins-Tanton, M. C. Rowe, and I. U. Peate (2012), Magnitude and consequences of volatile release from the Siberian Traps, Earth Planet. Sci. Lett., 317, 363-373.

Bowring, S. A., J. P. Grotzinger, D. J. Condon, J. Ramezani, and M. Newall (2007), Geochronologic constraints on the chronostratigraphic framework of the Neoproterozoic Huqf Supergroup, Sultanate of Oman, Am. J. Sci., 307, 1097-1145.

Buchan, K., S. Mertanen, R. Park, L. Pesonen, S.-Å. Elming, N. Abrahamsen, and G. Bylund (2000), Comparing the drift of Laurentia and Baltica in the Proterozoic: The importance of key palaeomagnetic poles, Tectonophysics, 319(3), 167-198.

Carazzo, G., and A. Jellinek (2013), Particle sedimentation and diffusive convection in volcanic ash-clouds, J. Geophys. Res. Solid Earth, 118, 1420-1437, doi:10.1002/jgrb.50155.

Chin, M., D. J. Jacob, G. M. Gardner, M. S. Foreman-Fowler, P. A. Spiro, and D. L. Savoie (1996), A global three-dimensional model of tropospheric sulfate, J. Geophys. Res., 101(D13), 18,667-18,690.

Clough, S., F. Kneizys, and R. Davies (1989), Line shape and the water vapor continuum, Atmos. Res., 23(3-4), 229-241.

Cox, G. M., C. F. Roots, G. P. Halverson, W. G. Minarik, F. A. Macdonald, and L. Hubert-Theou (2013), Mount Harper Volcanic Complex, Ogilvie Mountains: A far-flung occurrence of the Franklin igneous event, in Yukon Exploration and Geology 2012, edited by K. E. MacFarlane, M. G. Nordling, and P. J. Sack, pp. 19-36, Yukon Geological Survey, Whitehorse, Yukon.

Cox, G. M., J. V. Strauss, G. P. Halverson, M. D. Schmitz, W. C. McClelland, R. S. Stevenson, and F. A. Macdonald (2015), Kikiktat Volcanics of Arctic Alaska-Melting of harzburgitic mantle associated with the Franklin Large Igneous Province, Lithosphere, 7, 275-295, doi:10.1130/ L435.1.

Cox, G. M., G. P. Halverson, R. S. Stevenson, M. Vokaty, A. Poririer, M. Kunzmann, Z.-X. Li, F. O. Dudas, J. V. Strauss, and F. A. Macdonald (2016), A basalt weathering trigger for Snowball Earth, Earth Planet. Sci. Lett., 446, 89-99.

Denyszyn, S. W., D. W. Davis, and H. C. Halls (2009a), Paleomagnetism and U-Pb geochronology of the Clarence Head dykes, Arctic Canada: Orthogonal emplacement of mafic dykes in a large igneous province, Can. J. Earth Sci., 46, 155-167.

Denyszyn, S. W., H. C. Halls, D. W. Davis, and D. A. D. Evans (2009b), Paleomagnetism and U-Pb geochronology of Franklin dykes in High Arctic Canada and Greenland: A revised age and paleomagnetic pole for constraining block rotations in the Nares Strait region, Can. J. Earth Sci., 46, 689-705.

Dhomse, S., K. Emmerson, G. Mann, N. Bellouin, K. Carslaw, M. Chipperfield, R. Hommel, N. Abraham, P. Telford, and P. Braesicke (2014), Aerosol microphysics simulations of the Mt. Pinatubo eruption with the UM-UKCA composition-climate model, Atmos. Chem. Phys., 14(20), $11,221-11,246$.

Dostal, J., W. R. A. Baragar, and C. Dupuy (1986), Petrogenesis of the Natkusiak continental basalts, Victoria Island, Northwest Territories, Canada, Can. J. Earth Sci., 23, 622-632.

Ernst, R. E., et al. (2016), Long-lived connection between southern Siberia and northern Laurentia in the Proterozoic, Nat. Geosci., 9, 464-469. Evans, D. A. (2006), Proterozoic low orbital obliquity and axial-dipolar geomagnetic field from evaporite palaeolatitudes, Nature, 444, 51-55.

Fanning, C. M., and P. K. Link (2004), U-Pb SHRIMP ages of Neoproterozoic (Sturtian) glaciogenic Pocatello Formation, Geology, 32, 881-884. Feulner, G. (2012), The faint young Sun problem, Rev. Geophys., 50, doi:10.1029/2011RG000375.

Feulner, G., C. Hallmann, and H. Kienert (2015), Snowball cooling after algal rise, Nat. Geosci., 8, 659-662.

Ganino, C., and N. T. Arndt (2009), Climate changes caused by degassing of sediments during the emplacement of large igneous provinces, Geology, 37, 323-326.

Glaze, L. S., and S. M. Baloga (1996), Sensitivity of buoyant plume heights to ambient atmospheric conditions: Implications for volcanic eruption columns, J. Geophys. Res., 101(D1), 1529-1540, doi:10.1029/95JD03071.

Glaze, L. S., S. Self, A. Schmidt, and S. J. Hunter (2017), Assessing eruption column height in ancient flood basalt eruptions, Earth Planet. Sci. Lett., 457, 263-270.

Godderis, Y., Y. Donnadieu, A. Nedelec, B. Dupre, C. Dessert, A. Grard, G. Ramstein, and L. M. Francois (2003), The Sturtian 'snowball' glaciation: fire and ice, Earth Planet. Sci. Lett., 6648, 1-12.

Goldblatt, C., and K. Zahnle (2010), Clouds and the Faint Young Sun Paradox, Clim. Past Discuss., 6.

Grant, W. B., E. V. Browell, C. S. Long, L. L. Stowe, R. Grainger, and A. Lambert (1996), Use of volcanic aerosols to study the tropical stratospheric reservoir, J. Geophys. Res., 101(D2), 3973-3988.

Hansen, J. E., and L. D. Travis (1974), Light scattering in planetary atmospheres, Space Sci. Rev., 16(4), 527-610.

Hartmann, D. L. (2015), Global physical climatology, Newnes.

Heaman, L. M., A. N. LeCheminant, and R. H. Rainbird (1992), Nature and timing of Franklin igneous events, Canada: Implications for a Late Proterozoic mantle plume and the break-up of Laurentia, Earth Planet. Sci. Lett., 109, 117-131.

Hoffman, P. F., and D. P. Schrag (2002), The snowball Earth hypothesis: Testing the limits of global change, Terra Nova, 14(3), 129-155.

Jacobson, M. Z. (2005), Fundamentals of Atmospheric Modeling, Cambridge Univ. Press.

Jacobson, M. Z., R. P. Turco, E. J. Jensen, and O. B. Toon (1994), Modeling coagulation among particles of different composition and size, Atmos. Environ., 28(7), 1327-1338.

Jefferson, C. W., L. J. Hulbert, R. H. Rainbird, G. E. M. Hall, D. C. Gregoire, and L. I. Grinenko (1994), Mineral resource assessment of the Neoproterozoic Franklin Igneous Events of Arctic Canada: Comparison with the Permo-Triassic Noril'sk-Talnakh Ni-Cu-PGE deposits of Russia, Geol. Surv. Canada Open File, 2789, 48.

Jefferson, C., W. Nelson, R. Kirkham, J. Reedman, and R. Scoates (1985), Geology and copper occurrences of the Natkusiak basalts, Victoria Island, District of Franklin, Current Res. Part A: Geol. Surv. Canada Pap., 203-214.

Kasting, J. F., D. P. Whitmire, and R. T. Reynolds (1993), Habitable zones around main sequence stars, Icarus, 101(1), 108-128.

Kulmala, M., and A. Laaksonen (1990), Binary nucleation of water-sulfuric acid system: Comparison of classical theories with different $\mathrm{H}_{2} \mathrm{SO}_{4}$ saturation vapor pressures, J. Chem. Phys., 93(1), 696-701.

Lan, Z., X. Li, M. Zhu, Z.-Q. Chen, Q. Zhang, Q. Li, D. Lu, Y. Liu, and G. Tang (2014), A rapid and synchronous initiation of the wide spread Cryogenian glaciations, Precambrian Res., 255, 401-411.

Lan, Z., X.-H. Li, Q. Zhang, and Q.-L. Li (2015), Global synchronous initiation of the 2nd episode of Sturtian glaciation: SIMS zircon U-Pb and O isotope evidence from the Jiangkou Group, South China, Precambrian Res., 267, 28-38.

Li, Z.-X.,. E. D. A. D., and G. P. Halverson (2013), Neoproterozoic glaciations in a revised global palaeogeography from the breakup of Rodinia to the assembly of Gondwanaland, Sediment. Geology, 294, 219-232.

Liou, K.-N. (2002), An Introduction to Atmospheric Radiation, Academic Press. 
Macdonald, F. A., M. D. Schmitz, J. L. Crowley, C. F. Roots, D. S. Jones, A. C. Maloof, J. V. Strauss, P. A. Cohen, D. T. Johnston, and D. P. Schrag (2010), Calibrating the Cryogenian, Science, 327, 1241-1243.

Macdonald, F. A., E. F. Smith, J. V. Strauss, G. M. Cox, G. P. Halverson, and C. F. Roots (2011), Neoproterozoic and early Paleozoic correlations in the western Ogilvie Moutnains, Yukon, in Yukon Exploration and Geology 2010, edited by K. E. MacFarlane, L. H. Weston, and C. Relf, pp. 161-182, Yukon Geological Survey, Whitehorse.

Maher, K., and C. Chamberlain (2014), Hydrologic regulation of chemical weathering and the geologic carbon cycle, Science, 343, $1502-1504$.

Manabe, S., and R. T. Wetherald (1967), Thermal equilibrium of the atmosphere with a given distribution of relative humidity, J. Atmos. Sci., 24(241).

Marshall, H., J. C. G. Walker, and W. Kuhn (1988), Long-term climate change and the geochmical cycle of carbon, J. Geophys. Res., 93, 791-801, doi:10.1029/JD093iD01 p00791.

McCormick, M. P., L. W. Thomason, and C. R. Trepte (1995), Atmospheric effects of the Mt Pinatubo eruption, Nature, 373(6513), 399-404.

McKenzie, N. R., B. K. Horton, S. E. Loomis, D. F. Stockli, N. J. Planavsky, and C.-T. A. Lee (2016), Continental arc volcanism as the principal driver of icehouse-greenhouse variability, Science, 352(6284), 444-447.

Meador, W., and W. Weaver (1980), Two-stream approximations to radiative transfer in planetary atmospheres: A unified description of existing methods and a new improvement, J. Atmos. Sci., 37(3), 630-643.

Mills, B., A. J. Watson, C. Goldblatt, R. Boyle, and T. M. Lenton (2011), Timing of Neoproterozoic glaciations linked to transport-limited global weathering, Nat. Geosci., 4, 861-864.

Morton, B. R., G. Taylor, and J. S. Turner (1956), Proceedings of the Royal Society of London A: Mathematical, physical and engineering sciences, 234, 1-23.

Mustard, P. S., and C. F. Roots (1997), Rift-related volcanism, sedimentation, and tectonic setting of the Mount Harper Group, Ogilvie Mountains, Yukon Territory, Geol. Surv. Canada Bull., 492, -0-92.

Myhre, G., E. J. Highwood, K. P. Shine, and F. Stordal (1998), New estimates of radiative forcing due to well mixed greenhouse gases, Geophys. Res. Lett., 25(14), 2715-2718, doi:10.1029/98GL01908.

Nabelek, P. I., J. H. Bédard, and R. H. Rainbird (2014), Numerical constraints on degassing of metamorphic CO2 during the Neoproterozoic Franklin large igneous event, Arctic Canada, Geol. Soc. Am. Bull., 126(5-6), 759-772.

Neu, J. L., and R. A. Plumb (1999), Age of air in a "leaky pipe" model of stratospheric transport, J. Geophys. Res., 104(D16), 19,243-19,255.

Newton, R. C., and C. E. Manning (2005), Solubility of anhydrite, $\mathrm{CaSO} 4$, in $\mathrm{NaCl}-\mathrm{H} 2 \mathrm{O}$ solutions at high pressures and temperatures: Applications to fluid-rock interaction, J. Petrol., 46, 701-716.

Pehrsson, S. J., and K. L. Buchan (1999), Borden dykes of Baffin Island, Northwest Territories: A Franklin U-Pb baddelyite age and paleomagnetic reinterpretation, Can. J. Earth Sci, 36, 65-73.

Pierrehumbert, R. T. (2011), Principles of Planetary Climate, Cambridge University Press.

Pierrehumbert, R., D. Abbot, A. Voigt, and D. Koll (2011), Climate of the Neoproterozoic, Annu. Rev. Earth Planet. Sci., $39,417$.

Pinto, J. P., R. P. Turco, and O. B. Toon (1989), Self-limiting physical and chemical effects in volcanic eruption clouds, J. Geophys. Res., 94(D8), $11,165-11,174$.

Rainbird, R. H. (1993), The sedimentary record of mantle plume uplift preceding eruption of the Neoproterozoic Natkusiak flood basalt, J. Geol., 101, 305-318.

Rasch, P. J., S. Tilmes, R. P. Turco, A. Robock, L. Oman, C.-C. J. Chen, G. L. Stenchikov, and R. R. Garcia (2008), An overview of geoengineering of climate using stratospheric sulphate aerosols, Philos. Trans. R. Soc. London, Ser. A, 366, 4007-4037.

Read, W., L. Froidevaux, and J. Waters (1993), Microwave limb sounder measurement of stratospheric SO2 from the Mt. Pinatubo volcano, Geophys. Res. Lett., 20(12), 1299-1302, doi:10.1029/93GL00831.

Robertson, J., E. M. Ripley, S. J. Barnes, and C. Li (2015), Sulfur liberation from country rocks and incorporation in mafic magmas, Econ. Geol., 110, 1111-1123.

Rooney, A. D., F. A. Macdonald, J. V. Strauss, F. O. Dudas, C. Hallman, and D. Selby (2014), Re-Os geochronology and coupled Os-Sr isotope constraints on the Sturtian snowball Earth, Proc. Natl. Acad. Sci., 1073, 1-6.

Rooney, A. D., J. V. Strauss, A. D. Brandon, and F. A. Macdonald (2015), A Cryogenian chronology: Two long-lasting, synchronous Neoproterozoic Snowball Earth glaciations, Geology, 43, 459-462.

Russell, P., J. Livingston, R. Pueschel, J. Bauman, J. Pollack, S. Brooks, P. Hamill, L. Thomason, L. Stowe, and T. Deshler (1996), Global to microscale evolution of the Pinatubo volcanic aerosol derived from diverse measurements and analyses, J. Geophys. Res., 101(D13), $18,745-18,763$

Sander, S., D. Golden, M. Kurylo, G. Moortgat, P. Wine, A. Ravishankara, C. Kolb, M. Molina, B. Finlayson-Pitts, and R. Huie (2006), Chemical kinetics and photochemical data for use in atmospheric studies evaluation number 15, Rep., Jet Propul. Lab., National Aeronautics and Space Administration, Pasadena, Calif.

Schoene, B., J. C. Crowley, D. J. Condon, M. D. Schmitz, and S. A. Bowring (2006), Reassessing the uranium decay constants for geochronology using ID-TIMS U-Pb data, Geochim. Cosmochim. Acta, 70, 426-445.

Schoene, B., J. Guex, A. Bartolini, U. Schaltegger, and T. J. Blackburn (2010), Correlating the end-Triassic mass extinction and flood basalt volcanism at the 100 ka level, Geology, 38, 387-390.

Schrag, D. P., R. A. Berner, P. F. Hoffman, and G. P. Halverson (2002), On the initiation of snowball Earth, Geochem. Geophys. Geosyst., 3, 1-21, doi:10.1029/2001GC000219.

Segura, A., K. Krelove, J. F. Kasting, D. Sommerlatt, V. Meadows, D. Crisp, M. Cohen, and E. Mlawer (2003), Ozone concentrations and ultraviolet fluxes on Earth-like planets around other stars, Astrobiology, 3(4), 689-708.

Seinfeld, J. H., and S. N. Pandis (2016), Atmospheric Chemistry and Physics: From Air Pollution to Climate Change, John Wiley.

Self, S., T. Thordarson, and M. Widdowson (2005), Gas fluxes from flood basalt eruptions, Elements, 1, 283-287.

Self, S., M. Widdowson, T. Thordarson, and A. E. Jay (2006), Volatile fluxes during flood basalt eruptions and potential effects on the global environment: A Deccan perspective, Earth Planet. Sci. Lett., 248, 518-532.

Self, S., A. Schmidt, and T. Mather (2014), Emplacement characteristics, time scales, and volcanic gas release rates of continental flood basalt eruptions on Earth, Geol. Soc. Am. Spec. Pap., 505, SPE505-SPE516.

Serdyuchenko, A., V. Gorshelev, M. Weber, W. Chehade, and J. Burrows (2014), High spectral resolution ozone absorption cross-sections-Part 2: Temperature dependence, Atmos. Meas. Tech., 7, 625-636.

Sloan, L. C., and D. Rea (1996), Atmospheric carbon dioxide and early Eocene climate: A general circulation modeling sensitivity study, Palaeogeogr. Palaeoclimatol. Palaeoecol., 119(3), 275-292.

Stern, R. J., D. Avigad, N. Miller, and M. Beyth (2008), From volcanic winter to Snowball Earth: An alternative explanation for Neoproterozoic biosphere stress, in Links Between Geological Processes, Microbial Activities\&Evolution of Life, pp. 313-337, Springer. 
Stothers, R. B., J. A. Wolff, S. Self, and M. R. Rampino (1986), Basaltic fissure eruptions, plume heights, and atmospheric aerosols, Geophys. Res. Lett., 13(8), 725-728, doi:10.1029/GL013i008p00725.

Strauss, J. V., A. D. Rooney, F. A. Macdonald, A. D. Brandon, and A. H. Knoll (2014), 740 Ma vase-shaped microfossils from Yukon, Canada: Implications for Neoproterozoic chronology and biostratigraphy, Geology, G35736, 35,731.

Taylor, E. L., T. N. Taylor, and N. R. Cúneo (1992), The present is not the key to the past: A polar forest from the Permian of Antarctica, Science, 1675-1675.

Telling, J., and J. Dufek (2012), An experimental evaluation of ash aggregation in explosive volcanic eruptions, J. Volcanol. Geotherm. Res., 209, 1-8.

Textor, C., H. F. Graf, M. Herzog, and J. Oberhuber (2003), Injection of gases into the stratosphere by explosive volcanic eruptions, J. Geophys. Res., 108(D19), doi:10.1029/2002JD002987.

Thibodeau, A. M., and B. A. Bergquist (2017), Do mercury isotopes record the signature of massive volcanism in marine sedimentary records?, Geology, 45(1), 95-96.

Thordarson, T., and S. Self (1996), Sulfur, chlorine and fluorine degassing and atmospheric loading by the Roza eruption, Columbia River Basalt Group, Washington, USA, J. Volcanol. Geotherm. Res., 74(1), 49-73.

Thordarson, T., and S. Self (1998), The Roza Member, Columbia River Basalt Group: A gigantic pahoehoe lava flow field formed by endogenous processes?, J. Geophys. Res., 103(B11), 27,411-27,445.

Thordarson, T., and S. Self (2003), Atmospheric and environmental effects of the 1783-1784 Laki eruption: A review and reassessment, J. Geophys. Res., 108(D1), doi:10.1029/2001JD002042.

Thordarson, T., S. Self, N. Oskarsson, and T. Hulsebosch (1996), Sulfur, chlorine, and fluorine degassing and atmospheric loading by the 17831784 AD Laki (Skaftár Fires) eruption in Iceland, Bull. Volcanol., 58(2-3), 205-225.

Thordarson, T., S. Self, D. Miller, G. Larsen, and E. Vilmundardóttir (2003), Sulphur release from flood lava eruptions in the Veidivötn, Grímsvötn and Katla volcanic systems, Iceland, Geol. Soc. London, Spec. Publ., 213(1), 103-121.

Tisdale, R. T., D. L. Glandorf, M. A. Tolbert, and O. B. Toon (1998), Infrared optical constants of low-temperature H2SO4 solutions representative of stratospheric sulfate aerosols, J. Geophys. Res., 103(D19), 25,353-25,370.

Tollo, R. P., and J. N. Aleinikoff (1996), Petrology and U-PB geochronology of the Robertson River Igneous Suite, Blue Ridge province, Virginia -Evidence for multistage magmatism associated witn an early episode of Laurentian rifting, Am. J. Sci., 296(9), 1045-1090.

Turco, R., P. Hamill, O. Toon, R. Whitten, and C. Kiang (1979a), A one-dimensional model describing aerosol formation and evolution in the stratosphere: I. Physical processes and mathematical analogs, J. Atmos. Sci., 36(4), 699-717.

Turco, R., P. Hamill, O. Toon, R. Whitten, and C. Kiang (1979b), The NASA-AMES Research Center stratospheric aerosol model. 1. Physical processes and computational analogs.

Tziperman, E., I. Halevy, D. T. Johnston, A. H. Knoll, and D. P. Schrag (2011), Biologically induced initiation of Neoproterozoic snowball-Earth events, Proc. Natl. Acad. Sci., 108, 15,091-15,096.

Voigt, A., and J. Marotzke (2010), The transition from the present-day climate to a modern Snowball Earth, Clim. Dyn., 35, 887-905.

Voigt, A., D. Abbot, R. Pierrehumbert, and J. Marotzke (2011), Initiation of a Marnoun Snowball Earth in a state-of-the-art atmosphere-ocean general circulation model, Clim. Past, 7, 249-263.

Volk, C., J. Elkins, D. Fahey, and R. Salawitch (1996), Quantifying transport between the tropical and mid-latitude lower stratosphere, Science, 272(5269), 1763.

Williamson, N. M., L. Ootes, R. H. Rainbird, J. H. Bédard, and B. Cousens (2016), Initiation and early evolution of the Franklin magmatic event preserved in the 720 Ma Natkusiak Formation, Victoria Island, Canadian Arctic, Bull. Volcanol., 78, 1-19.

Wordsworth, R., and R. Pierrehumbert (2013a), Water loss from terrestrial planets with CO2-rich atmospheres, Astrophys. J., $778,154$.

Wordsworth, R., and R. Pierrehumbert (2013b), Hydrogen-nitrogen greenhouse warming in Earth's early atmosphere, Science, 339, 64-67.

Wordsworth, R., F. Forget, and V. Eymet (2010), Infrared collision-induced and far-line absorption in dense CO 2 atmospheres, Icarus, 210 , 992-997.

Wordsworth, R., F. Forget, E. Millour, J. Head, J. Madeleine, and B. Charnay (2013), Global modelling of the early Martian climate under a denser $\mathrm{CO} 2$ atmosphere: Water cycle and ice evolution, Icarus, 222, 1-19.

Wunsch, C., and R. Ferrari (2004), Vertical mixing, energy, and the general circulation of the oceans, Annu. Rev. Fluid Mech., 36, 281-314.

Xu, B., S. Xiao, H.-B. Zou, Y. Chen, Z.-X. Li, B. Song, D.-Y. Liu, C.-M. Zhou, and X.-L. Yuan (2009), SHRIMP zircon U-Pb age constraints on Neoproterozoic Quruqtah diamictites in NW China, Precambrian Res., 168, 247-258.

Yang, J., W. Peltier, and Y. Hu (2012), The initiation of modern soft and hard Snowball Earth climates in CCSM4, Clim. Past, 8, 907-918.

Young, G. M. (1981), The Amundsen Embayment, Northwest Territories: Relevance to the Upper Proterozoic evolution of North America, in Proterozoic Basins of Canada, edited by F. H. A. Campbell, pp. 203-218, Geol. Surv. Canada Pap., 81-10.

Zhang, Q.-R., X.-H. Li, L.-J. Feng, J. Huang, and S. Biao (2008), A new age constraint on the onset of the Neoproterozoic glaciations in the Yangtze Platform, South China, J. Geol., 116, 423-429.

Zhang, S., D. A. Evans, H. Li, H. Wu, G. Jiang, J. Dong, Q. Zhao, T. D. Raub, and T. Yang (2013), Paleomagnetism of the late Cryogenian Nantuo Formation and paleogeographic implications for the South China Block, J. Asian Earth Sci., 72, 164-177. 